\title{
Optimizing insect pest control and nitrogen fertilizing of the summer turnip rape (Brassica campestris sativa)
}

\begin{abstract}
SiRPA KURPPA and ANTTI OLLULA
KURPPA, S. \& OLLULA, A. 1993. Optimizing insect pest control and nitrogen fertilizing of the summer turnip rape (Brassica campestris sativa). Agric. Sci. Finl. 2: 149-160. (Agric. Res. Centre of Finland, Inst. Plant Protect., FIN-31600 Jokioinen, Finland.)

The need for pest control could not be decisively reduced by boosting the compensatory ability of the summer turnip rape with extra nitrogen fertilizer. The plant compensated the damage of the blossom beetle (Meligethes aenus $\mathrm{F}$.) by producing additional axillary racemes, pods and seeds. The compensation, in plant stands with about 300 plants $/ \mathrm{m} 2$, reached its maximum capacity with a nitrogen quantity of $90-110 \mathrm{~kg} /$ hectare and covered about $30 \%$ of the harvest loss inflicted by the large blossom beetle population. Only, when the blossom beetle population barely exceeded the control threshold (one beetle per plant at the early bud stage) harvest loss was fully compensated by the extra nitrogen. The damage inflicted by the flea beetles (Phyllotreta spp.) was better compensated, however, the importance of the preventive seed treatment became evident during dry and especially warm emergence periods, when the threshold of 30 holes per plant was exceeded. The use of extra nitrogen, above the moderate $70-90 \mathrm{~kg} / \mathrm{ha}$, was found to yield $400 \mathrm{~kg}$ per hectare at the most, with insecticides the yield increased maximally by more than $1000 \mathrm{~kg}$ per hectare. The moderate quantity of nitrogen was, also, sufficient to produce the best operating margin in the cultivation even in heavy mineral soils.
\end{abstract}

Key words: summer turnip rape, Meligethes aeneus, rape blossom beetle, flea beetle, Phyllotreta spp., nitrogen, pyrethrin, permethrin, compensation, operating margin

\section{Introduction}

The adaptability of cruciferous oilseed plants to varying growing conditions is generally good, and nitrogen in particular plays a key role in the compensation ability (TATCHELL 1983, AUGUSTINUSSEN 1987, LAMB 1989, AXELSEN and NIELSEN 1990). Determining the right proportions of nitrogen fertilization and fungicide treatments has been found to ensure steady yields and to be the essential factor in achieving a good economic result (HANUS and SCHOOP 1989). In Sweden, WALLGREN and RADBERG (1989) obtained the best economic re- sults with a nitrogen fertilization rate of $90 \mathrm{~kg} / \mathrm{ha}$ in their own experiments. In Finland, a nitrogen fertilization rate as high as $150 \mathrm{~kg} / \mathrm{ha}$ has been found to increase the yield of summer turnip rape. In the same experiment, application of the nitrogen fertilizer at two stages, i.e. two thirds at sowing and one third at the seedling stage, failed to increase the yield (KÖYLuÄrVI and PAHKALA 1989). The economic implications of using additional nitrogen were not compared in the experiment.

The species causing the most plant protection problems in the Finnish summer rape cultivation areas is the blossom beetle (Meligethes aeneus F.), 
Table 1. Soil type, acidity and nutrient content in the experimental fields in 1991-92.

\begin{tabular}{|c|c|c|c|c|c|c|}
\hline \multirow[t]{2}{*}{ Experimental site } & \multirow[t]{2}{*}{ Year } & \multirow[t]{2}{*}{ Soil type } & \multirow[t]{2}{*}{$\mathrm{pH}$} & \multicolumn{3}{|c|}{ Milligrams/litre } \\
\hline & & & & $\mathrm{Ca}$ & $\mathrm{P}$ & K \\
\hline \multirow[t]{2}{*}{ Jokioinen } & 1991 & Sandy clay & 6.0 & 2353 & 11.1 & 224 \\
\hline & 1992 & Sandy clay & 6.2 & 2473 & 13.6 & 178 \\
\hline \multirow[t]{2}{*}{ Lepaa } & 1991 & Gytja clay & 6.3 & - & 20.5 & 230 \\
\hline & 1992 & Gytja clay & 6.3 & - & 19.3 & 219 \\
\hline Mouhijärvi & 1991 & Silty clay & 6.0 & 1230 & 8.1 & 128 \\
\hline Pălkäne & 1991 & Finer fine sand & 5.5 & 1089 & 7.1 & 133 \\
\hline Ylistaro & 1991 & Mould & 5.4 & 2148 & 5.7 & 118 \\
\hline
\end{tabular}

although the crop losses ascribed to it have generally not exceeded $10 \%$ in fields sown with summer turnip rape (TULISALO and WUORI 1986). The pest control threshold for the blossom beetle is one beetle per plant at the early bud stage of the summer turnip rape, and 2 to 3 beetles per plant before blossoming, if the aim is to manage with one control spraying only. According to HOKKANEN et al. (1986), only the outer edges of the fields should be treated when the control threshold for the blossom beetle is lower.

This study of cultivation techniques aimed at identifying those agricultural and economic aspects that should be taken into account in extending the cultivation of turnip rape and rape to non-food agricultural use, optimizing production input, and creating ecologically more acceptable production methods. Production of rapeseed oil esters would be an alternative, if economic and ecological acceptability criteria could be met.

\section{Material and methods}

In 1991, field trials were carried out at five sites: in Jokioinen (60o 80' N, 23o 50' E), Lepaa (61o 11' $\mathrm{N}, 24$ o 37' E), Mouhijärvi (61o 51' N, 23o 01' E), Pälkäne (61o 32' N, 24o 28' E) and Ylistaro (62o 93' N, 22o 43' E), and in 1992 on two sites, i.e. Jokioinen and Lepaa. The soil types and fertility rates of the trial sites are shown in Table 1. As for the important phosphorous content (SAARELA and KÖYLIÄRVI 1989), the scale of adequate (Pälkäne, Ylistaro), fair (Jokioinen 1991, Mouhijärvi) and good (Jokioinen 1992 and Lepaa) was represented.
The experimental design followed the strip-plot arrangement, with randomized fertilizer and combined herbicide, fungicide, insecticide and growth regulator treatments. Trial plots, measuring 4 by 10 metres, were in replications of four. The experimental results were analyzed using MSTAT and SAS statistical software, especially using two-way analysis of variance. Significance levels are indicated in the tables with asterisks placed on the right hand side of the corresponding F-value as follows: *** $\mathrm{P}=0.001, * * \mathrm{P}=0.01$ and $* \mathrm{P}=0.05$.

The fertilizer levels, herbicide, fungicide, insecticide and growth regulator treatments used in field trials are shown below.

Year 1991:

al $70 \mathrm{~kg} \mathrm{~N} / \mathrm{ha}$

a2 $90 \mathrm{~kg} \mathrm{~N} / \mathrm{ha}$

a3 $110 \mathrm{~kg} \mathrm{~N} / \mathrm{ha}$

$* \mathrm{a} 470+20 \mathrm{~kg} \mathrm{~N} / \mathrm{ha}$ at seedling emergence

b1 no seed dressing or other treatments

b2 no seed dressing, rape blossom beetle controlled by pyrethrin

b3 herbicide, dressed seed, rape blossom beetle controlled by permethrin, plant growth regulator

*b4 herbicide, dressed seed, rape blossom beetle controlled by permethrin, plant growth regulator, couch grass control

* at Jokioinen only

Year 1992:

a1 $70 \mathrm{~kg} \mathrm{~N} / \mathrm{ha}$

a2 $110 \mathrm{~kg} \mathrm{~N} / \mathrm{ha}$

a3 $70+40 \mathrm{~kg} \mathrm{~N} / \mathrm{ha}$ at seedling emergence 
Table 2. Dates of sowing, plant protection and fertilizer treatments, and harvest in 1991-92.

\begin{tabular}{|c|c|c|c|c|c|c|c|}
\hline \multirow[b]{2}{*}{ Year Treatment } & \multicolumn{2}{|c|}{ Jokioinen } & \multicolumn{2}{|c|}{ Lepaa } & \multirow{2}{*}{$\frac{\text { Mouhijärvi }}{1991}$} & \multirow{2}{*}{$\begin{array}{c}\text { Pălkăne } \\
1991\end{array}$} & \multirow{2}{*}{$\begin{array}{c}\text { Ylistaro } \\
1991\end{array}$} \\
\hline & 1991 & 1992 & 1991 & 1992 & & & \\
\hline Sowing & 17.5. & 15.5. & 15.5 . & 20.5 . & 23.5 . & 22.5 . & 27.5 . \\
\hline Insecticide 1 & 26.6 . & 9.6 . & 27.6 . & 17.6. & 25.6 . & 28.6 . & 1.7. \\
\hline Insecticide $2^{*}$ & 8.7. & 15.6 . & - & - & - & - & 8.7. \\
\hline Foliage fertilizer & - & 15.6. & - & 17.7. & - & - & - \\
\hline Couch grass control ${ }^{* *}$ & 27.6 . & 15.6 . & - & 17.6. & - & 25.6 . & - \\
\hline Growth regulator & 1.7. & 25.6 . & 27.6 . & 29.6 . & 25.6 . & 28.6 . & 8.7. \\
\hline Additional $\mathrm{N}$ & 24.6 . & 16.6. & - & 17.6. & - & - & - \\
\hline Fungicide & - & 3.7 . & - & 9.7 & - & - & - \\
\hline Harvest & 13.9 . & 10.9 . & 9.9. & 11.9. & 18.9. & 24.9 . & 18.9. \\
\hline
\end{tabular}

- In Jokioinen extra insecticide sprayed 1.7.1991

** In Palkäne fluazephop butyl sprayed on the whole field.

Additional $\mathrm{N}=$ additional $\mathrm{N}$ at seedling emergence

b1 no seed dressing or other treatments

b2 no seed dressing, rape blossom beetle controlled by pyrethrin

b3 herbicide, dressed seed, rape blossom beetle controlled by permethrin

b4 herbicide, dressed seed, rape blossom beetle controlled by permethrin, couch grass control, foliage fertilizer, growth regulator, fungicide

The cultivation techniques followed normal practices as closely as possible. The growth stages of rape were graded by the BBHC-Decimal-Codes (WEBER and BLEIHOLDER 1990). The sowing density was 375 germinating seeds per square metre, the cultivars were 'KOVA' in 1991 and 'KULTA' in 1992.

Seed was dressed by Oftanol T (isofenphos 400 $\mathrm{g} / \mathrm{kg}$, thiram $100 \mathrm{~g} / \mathrm{kg}$ ) $20 \mathrm{~g} / \mathrm{kg}$ seeds. For basic fertilization, high nitrogen 'Typpirikas y-lannos 2' (N-P-K 20-4-8) was spread as band placement. Before tilling, treatments b3 and b4, which consisted of the herbicide 'Super Treflan' containing trifluralin $(480 \mathrm{~g} / \mathrm{l})$, in $19912.5 \mathrm{l} / \mathrm{ha}$ and in 19922 1/ha, were carried out. Natural pyrethrin in the form of 'Bioruiskute S' (100 g active ingredient/l), in $19910.5 \mathrm{l} / \mathrm{ha}$ and in $19920.6 \mathrm{l} / \mathrm{ha}$, and the permethrin preparation 'Ambush' (250 g active ingredient/l), in $19910.4 \mathrm{l} / \mathrm{ha}$ and in $19920.5 \mathrm{l} / \mathrm{ha}$, were used as insecticides against the blossom beetle. For additional nitrogen (in $199120 \mathrm{~kg} / \mathrm{ha}$, in 1992
$40 \mathrm{~kg} / \mathrm{ha}$ ) potassium nitrate 'Peltokalkkisalpietari' (N-P-K 15.5-0-0, Ca 19\%, Mg 0.2\%) was top dressed. Foliage fertilizer 'Rypsin lehtilannos 2' (N $3 \%, \mathrm{Mg} \mathrm{6 \%}$, Mn 5\%, B 3\%, Mo 0.5\%, S $11.2 \%$ ) was used at the rate of $4 \mathrm{~kg} / \mathrm{ha}$. 'Cerone' $(0.5 \mathrm{l} / \mathrm{ha})$, containing etefone $(480 \mathrm{~g} / \mathrm{l})$, was used as a growth control spray and 'Fusilade 2000', containing fluazephop butyl (125 g/l, $3 \mathrm{l} / \mathrm{ha})$, was used as herbicide for couch grass. The prochloraz 'Sportak 45 EC' (450 g/l, 1 l/ha), was used to control Sclerotinia rot. Water was used at the rate of 300 litres per hectare in the trials.

The control threshold of the blossom beetle was one beetle per plant at budding stage (BBHC 51 52 ), and two to three beetles per plant before blossoming (BBHC 53 - 54). Herbicide was sprayed on couch grass at the four or five leaf stage. Plant growth regulator was sprayed while the stems were gaining height but before blossoming (BBHC 53 54 ). Sclerotinia rot was controlled by spraying when the first petals were being shed (BBHC 63). In Jokioinen in the spring of 1992, seedlings in the plots sown with untreated seed were severely damaged by flea beetles (Phyllotreta spp.), necessitating an insecticide spray application of the experimental field, without which all the seedlings would have been consumed by the flea beetles. Permethrin ('Ambush' 0.5 1/ha) mixed with 300 litres of water per hectare was used as insecticide. The cultivation measures per trial site are shown in Table 2 . 
The experimental plots were investigated under the vegetative period as described in Table 3 . The method of NIELSEN and AXELSEN (1988) was used in screening the rape blossom beetle.

\section{Experimental conditions}

The experimental years were very different in terms of climatic conditions. In 1991, the beginning of May was cool and rainy. In Jokioinen, for instance, the cumulative degree-days of the growing season fell about $90^{\circ} \mathrm{C}$ short of the long-term average temperature by mid-June. In early August the weather turned warm, which accelerated the growth and ripening of the plants.

In 1992, May was warm and devoid of rainfall. In June and July the weather was warmer than normal. By mid-June the cumulative degree-days of the growing season exceeded the long-term average temperature by about $145^{\circ} \mathrm{C}$ in Jokioinen. The first rains that the plants could benefit from fell in mid-June. The following figure (Figure 1) and table

Table 3. Monthly precipitation ( $\mathrm{mm}$ ) for each experimental site in 1991-92.

\begin{tabular}{lcrrrrr}
\hline $\begin{array}{l}\text { Experimental } \\
\text { site }\end{array}$ & Year & May & June & July & Aug & Sep \\
\hline Jokioinen & 1991 & 29 & 69 & 55 & 92 & 80 \\
Jokioinen & 1992 & 7 & 25 & 47 & 153 & 19 \\
Lepaa & 1991 & 27 & 70 & 20 & 66 & 61 \\
Lepaa & 1992 & 12 & 36 & 64 & 92 & 97 \\
Mouhijärvi & 1991 & 32 & 69 & 29 & 71 & 92 \\
Pălkäne & 1991 & 22 & 88 & 41 & 193 & 68 \\
Ylistaro & 1991 & 56 & 147 & 26 & 60 & 88 \\
\hline
\end{tabular}

Table 4. Influence of seed dressing on the damage of flea beetles (Phyllotreta spp.), holes/plant in summer turnip rape at each trial site.

\begin{tabular}{|c|c|c|c|c|}
\hline \multirow{2}{*}{$\begin{array}{l}\text { Experimental } \\
\text { site } \\
\text { Year } \\
\text { Treatment }\end{array}$} & \multicolumn{2}{|c|}{ Jokioinen } & \multirow{2}{*}{$\frac{\text { Mouhijärvi }}{1991}$} & \multirow{2}{*}{$\frac{\text { Pälkäne }}{1991}$} \\
\hline & 1991 & 1992 & & \\
\hline No dressing & $5.5 \mathrm{a}$ & $35.4 \mathrm{a}$ & $5.6 \mathrm{a}$ & $4.9 \mathrm{a}$ \\
\hline Seed dressed & $3.4 \mathrm{~b}$ & $8.7 \mathrm{~b}$ & $2.5 \mathrm{~b}$ & $3.6 \mathrm{~b}$ \\
\hline F-value & $42.7^{* * *}$ & $1002.6^{* * *}$ & $51.1^{\cdots *}$ & $4.3^{\circ}$ \\
\hline
\end{tabular}

(Table 3) show the cumulative degree-days of the growing season $\left({ }^{\circ} \mathrm{C}\right)$ and monthly precipitation (mm) for each experimental site in 1991 and 1992.

\section{Results}

The weeds occurred only occasionally at all experimental sites and no yield loss could be attributed to the weeds.

\section{Efficacy of insect control}

In nearly all experiments seed dressing had a significant $(\mathrm{P}<0.01)$ effect on the damage inflicted by flea beetles on summer turnip rape (Table 4). In terms of yield, the damage observed during 1991 was insignificant. The damage inflicted by the flea beetle did not exceed the minimum damage density found to reduce the yield in the actual seed dressing trials, i.e. 30 holes per plant (cf. KURPPA 1991). The draught early in the summer of 1992 clearly hampered the emergence of summer turnip rape seedlings. The cotyledon stage of the seedlings lasted unusually long (over a month), which created conditions favourable for seedling damage to occur. The flea beetles would, in fact, have "cleaned out" the untreated plots if the seedlings had not been sprayed.

The size of the blossom beetle populations varied greatly between trial sites. Highly significant $(\mathrm{P}<0.01)$ reductions in population size were achieved through various insect control measures at almost all trial sites (Table 5). In plant stands treated with natural pyrethrin, the number of blossom beetles per plant was reduced by spraying, only to be restored within 48 hours to almost the same level as before the treatment. Permethrin treatments proved to be far more long acting at all trial sites, being effective for one week on average.

\section{Vegetational stem growth}

Stepwise increased nitrogen fertilisation boosted stem growth significantly $(\mathrm{P}<0.05)$ at two trial sites 

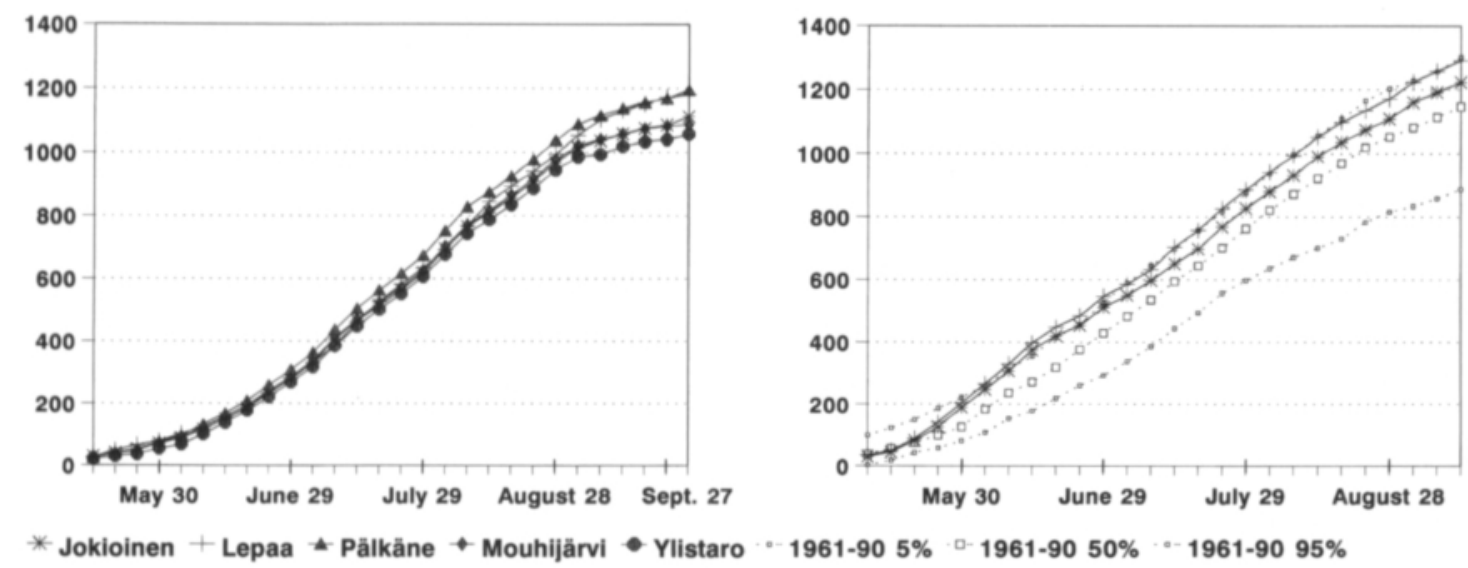

Fig. 1. The cumulative effective degree-days of the growing season for each trial site in 1991 - 92. Maximum values in 1991: Jokioinen (JOK) $1112^{\circ} \mathrm{C}$, Lepaa (LEP) $1181^{\circ} \mathrm{C}$, Pälkäne (PLK) $1195^{\circ} \mathrm{C}$, Mouhijärvi (MOUH) $1087^{\circ} \mathrm{C}$ and Ylistaro $1057^{\circ} \mathrm{C}$, in 1992: Jokioinen $1223^{\circ} \mathrm{C}$, Lepaa $1291^{\circ} \mathrm{C}$.

Table 5. Influence of insecticide spray on the number of rape blossom beetles (Meligethes aeneus) per plant in summer turnip rape at each trial site.

\begin{tabular}{|c|c|c|c|c|c|}
\hline \multirow{2}{*}{$\begin{array}{l}\text { Experimental site } \\
\text { Year Treatment }\end{array}$} & \multicolumn{2}{|c|}{ Jokioinen } & \multirow{2}{*}{$\frac{\text { Lepaa }}{1991}$} & \multirow{2}{*}{$\frac{\text { Mouhijärvi }}{1991}$} & \multirow{2}{*}{$\frac{\text { Pălkăne }}{1991}$} \\
\hline & 1991 & 1992 & & & \\
\hline Untreated & $3.4 \mathrm{a}$ & $20.8 \mathrm{a}$ & $0.5 \mathrm{a}$ & $1.7 \mathrm{a}$ & $2.6 \mathrm{a}$ \\
\hline Pyrethrin & $1.2 \mathrm{~b}$ & $7.6 \mathrm{~b}$ & $0.3 \mathrm{a}$ & $1.3 \mathrm{a}$ & $2.0 \mathrm{a}$ \\
\hline Permethrin & $1.6 \mathrm{~b}$ & $3.1 \mathrm{c}$ & $0.1 \mathrm{~b}$ & $1.0 \mathrm{~b}$ & $1.3 \mathrm{~b}$ \\
\hline F-value & $3.9^{\circ}$ & $90.1^{\cdots}$ & $5.9^{* *}$ & $5.9^{* *}$ & $13.9^{* \cdots}$ \\
\hline
\end{tabular}

(Pälkäne and Ylistaro) (Table 6). Ylistaro was the northernmost trial site with highest precipitation and situated on organic soil; Pälkäne had a fairly poor nutritional level in the soil, next highest June precipitation and low final yield (Table 1, 3, 10).

Etefone treatment reduced stem growth in the summer turnip rape significantly $(\mathrm{P}<0.05)$ in dry and nutritionally best trial sites (Jokioinen and Lepaa). This treatment, however, failed to show a significant effect on stem growth at the northernmost trial site (Ylistaro), where the vegetation grew highest. Insecticide and plant growth regulator sprayed in close succession ( 2 - 3 days between treatments), in 1991, resulted in a substantial reduction in stem growth, averaging $20 \mathrm{~cm}$ compared to the untreated plant stand. This was observed in nutritionally high standard clay soil in
Jokioinen, where the period immediately before and after the application was dry. The same treatment combination had not the same effect at other trial sites that were situated in finer sand, included lower quantities of calcium, phosphorous and potassium, and received a rain shower of $7.8 \mathrm{~mm}$ on the day of application.

\section{Vegetational branching}

In general terms the branching of summer turnip rape became poorer with increasing growth density. In 1991, the growing conditions were excellent at the trial site in Lepaa, where even minor measures designed to boost growth, e.g. increasing the quantity of nitrogen fertilizer, in addition to more effect- 
Table 6. Influence of the rate of nitrogen fertilization and pesticide treatments on the stem growth of summer turnip rape at each trial site.

\begin{tabular}{|c|c|c|c|c|c|c|c|}
\hline \multirow{2}{*}{$\begin{array}{l}\text { Experimental site } \\
\text { Year Treatment }\end{array}$} & \multicolumn{2}{|c|}{ Jokioinen } & \multicolumn{2}{|c|}{ Lepaa } & \multirow{2}{*}{$\frac{\text { Mouhijărvi }}{1991}$} & \multirow{2}{*}{$\frac{\text { Pălkäne }}{1991}$} & \multirow{2}{*}{$\frac{\text { Ylistaro }}{1991}$} \\
\hline & 1991 & 1992 & 1991 & 1992 & & & \\
\hline N 70 & 69 & 81 & 100 & 67 & - & $78 \mathrm{~b}$ & $101 \mathrm{~b}$ \\
\hline N 90 & 74 & - & 98 & - & 75 & 87 a & $107 \mathrm{ab}$ \\
\hline N 110 & 74 & 85 & 99 & 69 & 72 & 88 a & $105 \mathrm{ab}$ \\
\hline N $70+4^{1}$ & 71 & 86 & - & 67 & - & - & - \\
\hline LSD (0.05) & ns & ns & ns & ns & ns & 6.5 & 8.7 \\
\hline Untreated & $77 \mathrm{a}$ & $84 \mathrm{~b}$ & 103 a & $67 \mathrm{~b}$ & 72 & 85 & 111 \\
\hline Pyrethrin & $78 \mathrm{a}$ & $86 \mathrm{ab}$ & $102 \mathrm{a}$ & $68 \mathrm{~b}$ & 79 & 87 & 111 \\
\hline Permethrin ${ }^{2}$ & 75 a & 91 a & $90 \mathrm{~b}$ & $73 \mathrm{a}$ & 71 & 81 & 101 \\
\hline $\mathrm{P}+\mathrm{C}+\mathrm{F}+\mathrm{S}+\mathrm{FF}^{3}$ & $58 \mathrm{~b}$ & $77 \mathrm{c}$ & - & $62 \mathrm{c}$ & - & - & - \\
\hline LSD (0.05) & 4.7 & 5.5 & 10.4 & 3.2 & ns & ns & ns \\
\hline
\end{tabular}

1 Jokioinen $1991 \mathrm{~N} 70+20$

2 in 1991 with etefone

${ }^{3} \mathrm{P}+\mathrm{C}+\mathrm{F}+\mathrm{S}+\mathrm{FF}=$ permethrin, etefone, fluazephop butyl, prochloraz, foliage fertilizer exception: in 1991 Jokioinen prochloraz and foliage fertilizer missing

ive insecticide treatments, were observed to increase branching slightly despite the high growth density (304 plants/m2) (Table 7). In 1991, also the interaction of fertilizer and plant protection treatment was significant at the trial site in Jokioinen, where the plant stand (a4b1) given the most fertilizer and left without any treatments branched sig-

Table 7. Influence of the rate of nitrogen fertilization and pesticide treatments on the number of racemes/plant of summer turnip rape at each trial site.

\begin{tabular}{|c|c|c|c|c|}
\hline \multirow{2}{*}{$\begin{array}{l}\text { Experimental } \\
\text { site } \\
\text { Year } \\
\text { Treatment }\end{array}$} & \multicolumn{2}{|c|}{ Jokioinen } & \multirow{2}{*}{$\begin{array}{c}\text { Lepaa } \\
1991\end{array}$} & \multirow{2}{*}{$\begin{array}{c}\begin{array}{c}\text { Mouhi- } \\
\text { järvi }\end{array} \\
1991\end{array}$} \\
\hline & 1991 & 1992 & & \\
\hline N 70 & 4.2 & 7.5 & $3.5 \mathrm{~b}$ & 7.0 \\
\hline N 90 & 4.9 & - & $3.9 \mathrm{a}$ & 5.5 \\
\hline N 110 & 4.9 & 7.7 & $4.2 \mathrm{a}$ & 5.8 \\
\hline N $70+40^{1}$ & 5.2 & 7.4 & - & - \\
\hline F-value & $2.3 \mathrm{~ns}$ & $0.2 \mathrm{~ns}$ & $3.3^{\circ}$ & $2.6 \mathrm{~ns}$ \\
\hline Untreated & 4.9 & $8.8 \mathrm{a}$ & $3.8 \mathrm{~b}$ & $7.2 \mathrm{a}$ \\
\hline Pyrethrin & 5.3 & $9.8 \mathrm{a}$ & $3.4 \mathrm{~b}$ & $5.5 \mathrm{~b}$ \\
\hline Permethrin ${ }^{2}$ & 4.9 & $6.0 \mathrm{~b}$ & $4.3 \mathrm{a}$ & $5.5 \mathrm{~b}$ \\
\hline $\mathrm{P}+\mathrm{C}+\mathrm{F}+\mathrm{S}+\mathrm{FF}^{3}$ & 4.1 & $5.7 \mathrm{~b}$ & - & - \\
\hline F-value & ns & $18.6^{* * *}$ & $5.2^{*}$ & $4.4^{*}$ \\
\hline Interaction & $2.3^{\circ}$ & ns & ns & ns \\
\hline
\end{tabular}

Jokioinen $1991 \mathrm{~N} 70+20$

2 in 1991 with etefone

${ }^{3} \mathrm{P}+\mathrm{C}+\mathrm{F}+\mathrm{S}+\mathrm{FF}=$ permethrin, etefone, fluazephop butyl, prochloraz, foliage fertilizer

exception: in 1991 Jokioinen prochloraz and foliage fertilizer missing nificantly more than any other plant stand, averaging 6.7 racemes per plant.

\section{Crop blossoming period}

Combination of the plant protection treatments had a very significant $(\mathrm{P}<0.01)$ effect on the length of the blossoming period of summer turnip rape, which for the untreated plant stand averaged 16 days, whereas that of the chemically treated plant stand was nearly 6 days longer. In the plant stand treated with natural pyrethrin, a slight increase (1 day) in the blossoming period was observed, compared with the untreated plant stand. The presence of a large number of blossom beetles and their larvae in the blossoms led to the rapid withering of the blossoms in the plant stands treated with natural pyrethrin or left untreated.

\section{Number of pods and seeds}

Using more fertilizer boosted the number of pods per raceme at least up to the $90 \mathrm{~kg} / \mathrm{ha}$ level, with the exception of the trial site in Mouhijärvi, where a strong contradictory trend was observed. There the interaction of fertilizer and control treatment was significant, the highest quantity of pods per raceme 
being found in treatment (a1b3) consisting of the smallest quantity of fertilizer and the best plant protection treatment. Permethrin treatment increased the quantity of pods per raceme most noticeably at the trial sites with the largest blossom beetle populations (Table 8 ).

The use of fertilizer and the combination of plant protection treatments resulted in a significant difference in the number of seeds per pod (Table 9). The interaction of fertilizer and plant protection treatments was highly significant in the 1991 trial in Jokioinen, where the highest average number of seeds per pod, 23.6, was observed with the treatment including the largest quantity of fertilizer and the most abundant plant protection treatments.

\section{Final yield}

In 1992, the effect of plant protection treatments on yield was highly significant $(\mathrm{P}<0.01)$ at the trial sites with the best growing conditions, in Jokioinen and Lepaa (Table 10). In the present experiment pyrethrin treatment either failed to increase the turnip rape yield per hectare, or the increase was only slight (in Jokioinen $112 \mathrm{~kg} / \mathrm{ha}$, in Lepaa $60 \mathrm{~kg} / \mathrm{ha}$ in 1992), which in a way demonstrated that the preparation was too short-acting for the blossom beetle. The best increases in yield were obtained with permethrin treatments (up to $1000 \mathrm{~kg}$ ) at the trial sites with the largest blossom beetle populations.

Plant growth regulator used together with couch grass herbicide reduced the yield in Jokioinen. These results seem to indicate that caution should be exercised in using herbicides for couch grass together with plant growth regulators when growing summer turnip rape, or that sufficiently long intervals between spray application should, at least, be allowed.

The top yield was achieved in 1991 with treatments including fertilizer at the rate of $110 \mathrm{~kg} \mathrm{~N} / \mathrm{ha}$ $(1653 \pm 102 \mathrm{~kg} / \mathrm{ha})$, and in 1992 the highest rate was achieved with treatments including $70+40 \mathrm{~kg}$ $\mathrm{N} / \mathrm{ha}(2163 \pm 69 \mathrm{~kg} / \mathrm{ha})$. And yet, increasing the quantity of nitrogen had a significant effect in only two cases out of seven, ranging between 70 and 110 kg (Table 10).
Table 8. Influence of the rate of nitrogen fertilization and pesticide treatments on the number of pods/raceme of summer turnip rape at each trial site.

\begin{tabular}{|c|c|c|c|c|}
\hline \multirow{2}{*}{$\begin{array}{l}\text { Experimental } \\
\text { site } \\
\text { Year } \\
\text { Treatment }\end{array}$} & \multicolumn{2}{|c|}{ Jokioinen } & \multirow{2}{*}{$\begin{array}{c}\text { Lepaa } \\
1991\end{array}$} & \multirow{2}{*}{$\begin{array}{c}\begin{array}{c}\text { Mouhi- } \\
\text { jărvi }\end{array} \\
1991\end{array}$} \\
\hline & 1991 & 1992 & & \\
\hline N 70 & $6.5 \mathrm{~b}$ & 58.0 & $26.7 \mathrm{~b}$ & 40.0 \\
\hline N 90 & $25.6 \mathrm{a}$ & - & $31.5 \mathrm{~b}$ & 36.3 \\
\hline N 110 & $22.1 \mathrm{a}$ & 63.1 & $44.2 \mathrm{a}$ & 35.1 \\
\hline N $70+40^{1}$ & $19.5 \mathrm{a}$ & 65.4 & - & - \\
\hline F-value & $4.6^{\circ *}$ & ns & $10.2^{* *}$ & ns \\
\hline Untreated & $13.0 \mathrm{~b}$ & 56.8 & $32.0 \mathrm{~b}$ & 40.1 \\
\hline Pyrethrin & $14.4 \mathrm{~b}$ & 67.2 & $28.9 \mathrm{~b}$ & 34.0 \\
\hline Permethrin ${ }^{2}$ & $30.4 \mathrm{a}$ & 63.7 & $39.2 \mathrm{a}$ & 36.7 \\
\hline $\mathrm{P}+\mathrm{C}+\mathrm{F}+\mathrm{S}+\mathrm{FF}^{3}$ & 24.9 & 60.1 & - & - \\
\hline F-value & $23.0^{* * *}$ & ns & $3.7^{\circ}$ & ns \\
\hline Interaction & ns & ns & ns & $2.62^{\circ}$ \\
\hline
\end{tabular}

1 Jokioinen 1991 N $70+20$

2 in 1991 with etefone

${ }^{3} \mathrm{P}+\mathrm{C}+\mathrm{F}+\mathrm{S}+\mathrm{FF}=$ permethrin, etefone, fluazephop butyl, prochloraz foliage fertilizer exception: in 1991 Jokioinen prochloraz and foliage fertilizer missing

Table 9. Influence of the rate of nitrogen fertilization and pesticide treatments on the number of seeds/pod of summer turnip rape at each trial site.

\begin{tabular}{llc}
\hline $\begin{array}{l}\text { Experimental site } \\
\text { Treatment }\end{array}$ & Jokioinen & Mouhijärvi \\
\hline N 70 & 17.2 & $20.3 \mathrm{ba}$ \\
N 90 & $19.1 \mathrm{ab}$ & $19.6 \mathrm{ab}$ \\
N 110 & $20.5 \mathrm{~b}$ & $17.5 \mathrm{a}$ \\
N $70+20$ & $20.1 \mathrm{~b}$ & - \\
F-value & $5.82^{* * *}$ & $4.33^{*}$ \\
Untreated & $18.7 \mathrm{a}$ & $19.7 \mathrm{~b}$ \\
Pyrethrin & $18.7 \mathrm{a}$ & $17.1 \mathrm{a}$ \\
Permethrin' & $20.8 \mathrm{~b}$ & $20.5 \mathrm{c}$ \\
P + C + F & $18.8 \mathrm{ab}$ & \\
F-value & $2.79^{*}$ & $6.36^{* *}$ \\
Interaction & $6.12^{* *}$ & $\mathrm{~ns}$ \\
\hline
\end{tabular}

1 with etefone

The increase in turnip rape yield, obtained with fertilizer and plant protection treatments, was attributable to different yield factors at various trial sites. The best initial growth was observed at a trial site with best nutritional conditions (phosphorous especially) in Lepaa, where the higher yield was 
Table 10. Influence of the rate of nitrogen fertilization and pesticide treatments on the yield ( $\mathrm{kg} / \mathrm{ha}$ ) of summer turnip rape at each trial site.

\begin{tabular}{|c|c|c|c|c|c|c|c|}
\hline \multirow{2}{*}{$\begin{array}{l}\text { Experimental site } \\
\text { Year Treatment }\end{array}$} & \multicolumn{2}{|c|}{ Jokioinen } & \multicolumn{2}{|c|}{ Lepaa } & \multirow{2}{*}{$\frac{\text { Mouhijärvi }}{1991}$} & \multirow{2}{*}{$\frac{\text { Pälkäne }}{1991}$} & \multirow{2}{*}{$\frac{\text { Ylistaro }}{1991}$} \\
\hline & 1991 & 1992 & 1991 & 1992 & & & \\
\hline N 70 & 1051 & 2192 & $2851 \mathrm{~b}$ & 1867 & 1001 & $709 \mathrm{~b}$ & 1370 \\
\hline N 90 & 1402 & - & 3124 a & - & 1102 & $1105 \mathrm{a}$ & 1439 \\
\hline N 110 & 1334 & 2333 & 3185 a & 1884 & 1299 & $1064 \mathrm{a}$ & 1489 \\
\hline$N 70+40^{1}$ & 1310 & 2389 & - & 1935 & - & - & - \\
\hline LSD $(0.05)$ & ns & ns & 242 & ns & ns & 160 & ns \\
\hline Untreated & $788 \mathrm{c}$ & $1959 \mathrm{c}$ & 2951 & $1603 \mathrm{~b}$ & $1101 \mathrm{~b}$ & 922 & 1420 \\
\hline Pyrethrin & $877 \mathrm{c}$ & $2071 \mathrm{~b}$ & 3048 a & $1663 \mathrm{~b}$ & $1030 \mathrm{~b}$ & 912 & 1484 \\
\hline Permethrin ${ }^{2}$ & 1835 a & 2613 a & 3161 & 2097 a & $1271 \mathrm{a}$ & 1044 & 1394 \\
\hline $\mathrm{P}+\mathrm{C}+\mathrm{F}+\mathrm{S}+\mathrm{FF}^{3}$ & $1597 \mathrm{~b}$ & 2578 a & - & 2218 a & - & - & - \\
\hline LSD (0.05) & 142 & 79 & ns & 140 & 108 & ns & ns \\
\hline
\end{tabular}

1 Jokioinen in $1991 \mathrm{~N} 70+20$

2 in 1991 with etefone

${ }^{3} \mathrm{P}+\mathrm{C}+\mathrm{F}+\mathrm{S}+\mathrm{FF}=$ permethrin, 'etefone', fluazephop butyl, prochloraz, foliage fertilizer exception: in 1991 Jokioinen prochloraz and foliage fertilizer missing

due to slight increases in branching and number of pods per raceme (Tables 7 and 8 ). In the plant stand in Mouhijärvi, with the poorest initial growth pattern, the increase in yield was due to slight increases in growth density and number of seeds per pod (Table 9). In Jokioinen, which was a kind of average between the two sites mentioned above, the higher yield was attributable to increases in the quantity of racemes and number of seeds per pod (Tables 7 and 9).

\section{Profitability of cultivation}

In this experiment the profitability of cultivation was assessed in terms of the operating margin, in other words, by deducting from the gross profit the variable cost items, i.e. expenses directly attributable to the cultivation of the plant in question. The following list shows the unit prices on which the operating margin calculations were based, and the operating margin of summer turnip rape in Finnish marks (FIM/ha) per each treatment during 1991 and 1992 (prices are standard prices of 1991).

Yield: summer turnip rape $4.053 \mathrm{FIM} / \mathrm{kg}$ (no marketing tax included)
Variable production costs:

- seed (not dressed) $15 \mathrm{FIM} / \mathrm{kg}$

- seed (dressed) 24 FIM/kg

- preparatory work and drilling $250 \mathrm{FIM} / \mathrm{ha}$

- herbicide, 'Super Treflan' (trifluralin) + treatment cost 284 FIM/l

- fertilizer, 'Typpirikas Y-lannos 2' 1.94 FIM/kg

- fertilizer for additional nitrogen, 'Peltokalkkisalpietari' $1.61 \mathrm{FIM} / \mathrm{kg}$

- foliage fertilizer, 'Rypsin lehtilannos', 17.50 $\mathrm{FIM} / \mathrm{kg}$

- insecticide, 'Bioruiskute S' (pyrethrin) 208 FIM/l

- insecticide, 'Ambush' (permethrin) 402 FIM/1

- plant growth regulator, 'Cerone' (etefone) 227 FIM/l

- fungicide 'Sportak 45 EC' (prochloraz), 246 FIM/kg

- herbicide for couch grass control, 'Fusilade 2000' (fluazephop butyl), 284 FIM/l

- extra fertilizing or plant protection spray, labour and machinery, $65 \mathrm{FIM} / \mathrm{ha} /$ application

- combine harvest $780 \mathrm{FIM} / \mathrm{ha}$

- drying $0.12 \mathrm{FIM} / \mathrm{kg}$

To obtain an economically acceptable result, it is necessary that the field to be sown is in a good 
condition and free of annual and perennial weeds, as herbicide treatments can easily become a noticeable cost factor in the cultivation of summer turnip rape.

In most cases the treatment including the most fertilizer $(110 \mathrm{~kg} \mathrm{~N} / \mathrm{ha})$ gave the best operating margin, although the difference was minor. In 1991 , the difference between the nitrogen levels of $90 \mathrm{~kg} / \mathrm{ha}$ and $110 \mathrm{~kg} / \mathrm{ha}$ were not statistically significant at any trial site, and a difference in effect between nitrogen levels of $70 \mathrm{~kg} / \mathrm{ha}$ and $90 \mathrm{~kg} / \mathrm{ha}$ on various organic soils could not be demonstrated. On the basis of the above, the optimum quantity of nitrogen fertilizer was assessed to range between 70 and $90 \mathrm{~kg} / \mathrm{ha}$.

When the control threshold of the blossom beetle was barely exceeded, i.e. there was one beetle per plant at the early bud stage, natural pyrethrin treatment alone gave a satisfactory economic result (1991 trial in Lepaa, Fig. 2). When blossom beetles were more plentiful, a satisfactory or good economic result necessitated repeated treatments with synthetic pyrethroid (cf. 1992 trial in Jokioinen, Fig. 2).

\section{Discussion}

Current guidelines for cultivating turnip rape include a recommendation for relatively high levels of nitrogen fertilizer, compared with the results obtained in summer rape trials in Denmark (cf. AUGUSTINUSSEN 1987). In the present study, however, raising the nitrogen fertilizer level from 70 $\mathrm{kg} /$ ha to $110 \mathrm{~kg} / \mathrm{ha}$ increased the yield in only one third of the trials, by about $400 \mathrm{~kg} / \mathrm{ha}$ at the best, and the use of nitrogen failed to compensate adequately for the omission of insect pest control measures, the effect of which peaked $1000 \mathrm{~kg} / \mathrm{ha}$ at its worst.

In Finnish turnip rape plant stands of normal density (generally more than 200 plants per $\mathrm{m} 2$ ), compensation by cruciferous oilseed plants by means of branching cannot influence the result through prolific growth, unlike plant stands of about half the density (cf. TATCHELL 1983, AUGUSTINUSSEN 1987, NILSSON 1988, AXELSEN and NIELSEN 1990). The utilization of nitrogen during dry summers will in all likelihood be poor, and the additional nitrogen will not boost compensation in the manner demonstrated elsewhere (cf. DAEBELER at al. 1980). In dry conditions, massive invasions by blossom beetles have been demonstrated to cause stunted growth on top of the shoots, as reported by NILSSON (1988). Due to the unpredictability of the growing conditions in Finland, fertilizer levels around $90 \mathrm{~kg} / \mathrm{ha}$ would seem to effectively ensure a reasonable compensation capacity in the summer turnip rape of a cultivar similar to 'Kulta', even in heavy mineral soils. Under good growing conditions, and in organic soils, 70 $\mathrm{kg} / \mathrm{ha}$ of fertilizer will suffice; in other words the minimum quantities of fertilizer recommended by KÖYLJÄRVI and PAHKALA (1989), or even slightly less, would seem sufficient.

In 1991, the damage observed in summer turnip rape seedlings, which was attributed to the flea beetle, was of hardly any consequence to the yield. The flea beetle population barely exceeded the control threshold of one flea beetle per plant suggested by AUGUSTIN et al. (1986). When the beetle population is large, however, and the emergence of seedlings is slow due to a cold or dry early spring, seed dressing results in denser and more robust plant stands than would be the case with untreated seed. In a poor year, such as 1992, the plant stands sown with undressed seed might be totally destroyed in some areas. To avoid total destruction, insecticide spraying will be necessary at the seedling stage, like in the 1992 trials. The extent of the damage inflicted by the flea beetle depends largely on the weather, and in Finnish long-term experiments reduced yields attributable to this cause have been found to occur every three years on average (KURPPA 1991). In the absence of resistance, one pest control measure applicable to the flea beetle would be seed dressing with pyrethrin, but its effectiveness in dry summers should be improved (Ketola 1992, pers. commun.).

The control threshold of the blossom beetle of one insect per plant at an early bud stage was confirmed as correct by the results of the present experiment. This control threshold is low compared to the conditions in Central Europe (cf. SEIDEL and 


\section{Jokioinen 1991}
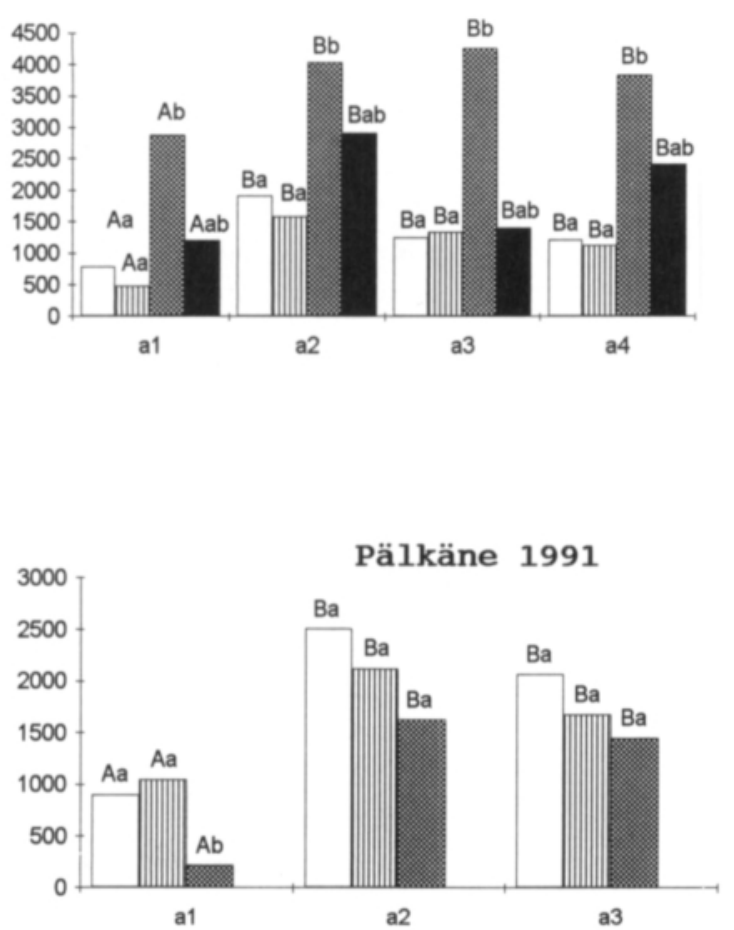

\section{Ylistaro 1991}

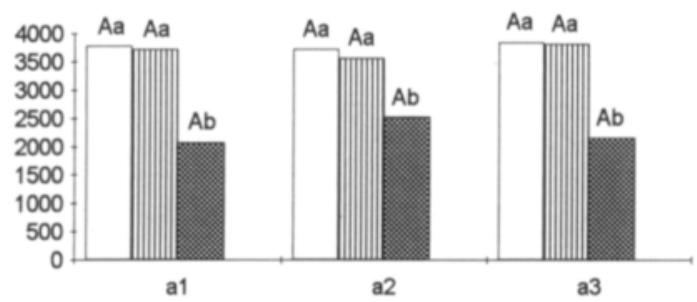

Lepaa 1992

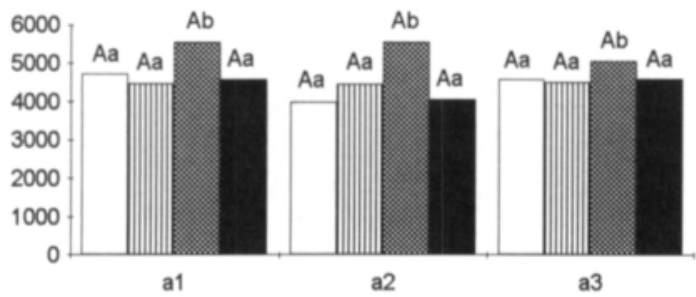

Lepaa 1991

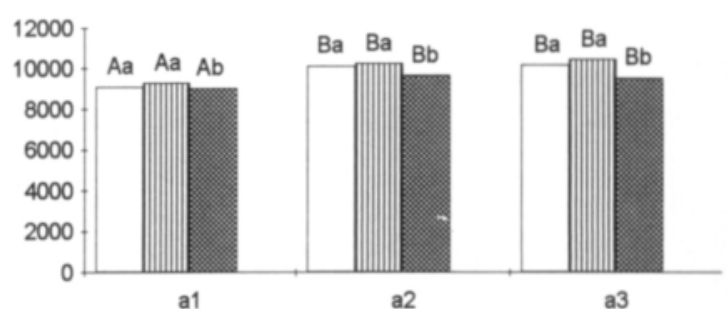

Mouhijärvi 1991

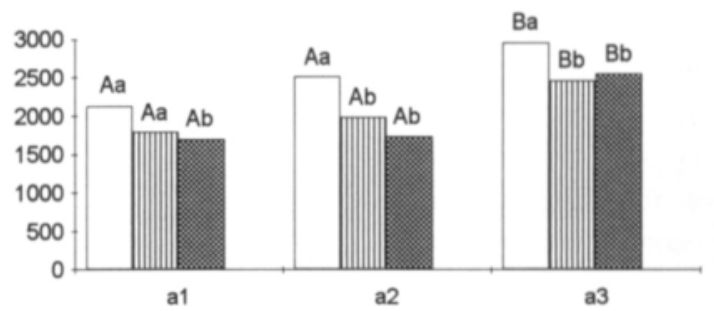

Jokioinen 1992

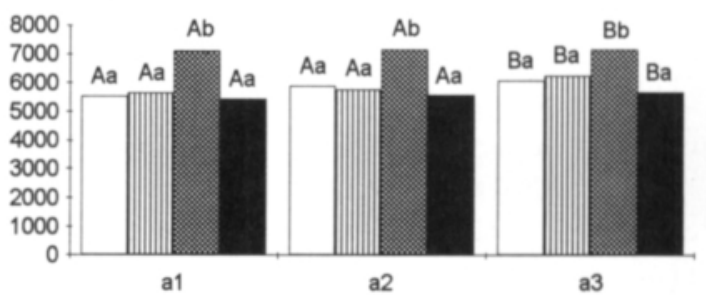

Fig. 2. The operating margin in the production of summer turnip rape (FIM/ha) in 1991 and 1992 at each trial site. Above the columns significant differences $(0.05)$ between the nitrogen treatments are indicated by capitals (A, B, C) and between pesticide treatments by small letters $(\mathrm{a}, \mathrm{b}, \mathrm{c})$. 
DAEBELER 1986, VIETINGHOFF and DAEBELER 1986), but the difference is mainly due to varying growth densities of summer turnip rape plant stands. In Central Europe the main importance is also given to winter turnip rape, which is not as sensitive to pollen beetle damage as the summer variety. The profuse branching of the plant stands treated with natural pyrethrin or left untreated is an indication of the compensatory tendency of plant stands and the limited effect of pyrethrin. Turnip rape also tends to compensate the damage inflicted on embryonic buds by the beetle by producing additional small buds, which will develop to raceme containing relatively few seeds, as has been reported earlier (NILSSON 1988). According to good cultivation practices, the pest control measures against the blossom beetle should include a pyrethrin spraying as soon as the control threshold for the blossom beetle is exceeded, followed by a second application using synthetic pyrethroid when the later threshold of two or three insects per plant is exceeded. The aim of the pyrethrin spraying is to reduce the beetle population as effectively as possible (af. SEIDEL et al. 1991). The second spraying has to be done before the cumulative degreedays value of $320 \mathrm{oC}$ has been reached, to avoid destroying the parasites of the beetles (af. HOKKANEN et al. 1988).
To optimize the production of the summer turnip rape as an alternative crop for use as non-food raw material and simultaneously to minimize the chemical control and the deleterious and impoverishing ecological effects on the environment, the following principles should be applied:

1. Only use soil with sufficient $\mathrm{pH}$, and phosphorous content

2. A sufficient quantity of fertilizer nitrogen in mineral soil is not higher than $90 \mathrm{~kg} \mathrm{~N} / \mathrm{ha}$ and in organic soil $70 \mathrm{~kg} \mathrm{~N} / \mathrm{ha}$.

3. Seed dressing not necessary in soils advantageous to seedling emergence (light mineral or organic soil)

4. Apply insecticides against rape pollen beetle according to the appearance and abundance of the beetles.

5. Use herbicides only as necessary.

6. Take extreme precautions when using growth regulators especially in combination with couch grass control.

Acknowledgements. This research was part of a project of the Ministry of Agriculture, 'The production of rapeseed oil esters for use as diesel fuel', performed in cooperation with the Finnish rapeseed oil refineries and the Agricultural Research Centre. Special thanks are due to the project leader, Prof. Unto Tulisalo, and to the staff of the experimental stations for technical assistance.

\section{References}

Augustin, A., Tulisalo, U. \& Korpela, S. 1986. Flea beetles (Coleoptera, Chrysomelidae, Halticinae) on rapeseed and sugarbeet in Finland. J. Agric. Sci. Finl. 58: 69-82.

Augustinussen, E. 1987. Kvaelstofgødskningens indflydelse på vaekst og udvikling af vårraps: The influence of nitrogen fertilizing on growth and development of spring oilseed rape. Tidsskr. Planteavl 91: 33-44.

AXelsen, J. \& Nielsen, P. S. 1990. Compensation in spring sown oilseed rape after attack by pollen beetles. (Meligethes aeneus F.) Tidsskr. Planteavl 94: 195-199.

Daebeler, F., Röder, K., Hinz, B. \& LOCKe, W. 1980. Schadwirkung des Rapsglanzkäfers bei unterschiedlich hohen Stickstoffgaben. Nachr.bl. Pfl.schutz 34: 13-15.

Hanus, H. \& SCHOOP, P. 1989. Influence of nitrogen fertilizer and fungicide on yield and yield variability in wheat and barley. In: Anderson, J. R. \& Hazell, P. B. R. (eds.). Variability in grain yields: implications for agricultural research and policy in developing countries. Baltimore,
Maryland, USA; John Hopkins University Press. p. 265269.

Hokkanen, H. M. T., Granlund, H., Husberg, G.B. \& MarkKula, M. 1986. Trap crops used succesfully to control Meligethes aeneus (Col., Nitidulidae), the rape blossom beetle. Ann. Ent. Fenn. 52: 115-120.

— , Husberg, G.-B. \& Söderblom, M. 1988. Natural enemy concervation for the integrated control of the rape blossom beetle Meligethes aeneus F. Ann. Agric. Fenn. 27: 281-294.

KôYLü̃Rvı, J. \& PAHKALA, K. 1989. Kevätöljykasvien typpilannoitus ja sen ajoittaminen. In: Pahkala, K. (ed.). Öljykasvien viljelyn edistäminen. Maatalouden tutkimuskeskus Tiedote 11/89. p. 38-51.

KURPPA, S. 1991. Betning av vårrybs - 10 års resultat. NJF's sektion II - Plantedyrkning. Seminar 202. Roskilde, Danmark p. 219-223.

LAMB, R. J. 1989. Entomology of oilseed brassica crops. 
Ann. Rev. Ent. 34: 211-229.

Nielsen, P. S. \& AXelsen, J. 1988. Spatial distribution of the pollen beetle (Meligethes aeneus $\mathrm{F}$.) in spring sown rape (Brassica napus L.) in Denmark, and its importance for sampling. J. Appl. Ent. 105: 35-40.

NiLsson, C. 1988. Pollen beetles (Meligethes aeneus F.) and Flowering in rape. Swedish J. Agric. Res. 18: 113-118.

SaARela, I. \& KöYLUÄRVI, J. 1989. Öljykasvien fosfori-, kalium-, rikki- ja boorilannoitus sekä muiden ravinteiden ja kalkituksen tarve. In: Pahkala, K. (ed.). Öljykasvien viljelyn edistäminen. Maatalouden tutkimuskeskus Tiedote $11 / 89$. p. 52-60,

Seidel, D., Kdimati, H. \& Daebeler, F. 1991. Reduction of the following generation of pollen beetle by previous insecticide treatment. IOBC/WPRS Bull. 14, 6: 229-233.

— \& Daebeler, F. 1986. Neue Ergebnisse zur Bekämpfungsentscheidung bei Rapsschädlingen: Recent results regarding decision making for control of insect pests in rape fields. Nachr.bl. Pfl.schutz 40: 157-160.

TAtChelL, G. M. 1983. Compensation in spring-sown oilseed rape (Brassica napus L.) plants in response to injury to their flower buds and pods. J. Agric. Sci., Camb. 101: 565-573.
Tulisalo, U. \& Wuori, T. 1986. Blossom beetle (Meligethes aeneus Fab. as a yield factor in turnip rape (Brassica camptestris L.) J. Agric. Sci. Finl. 58: 221-237.

VIETINGHoff, J. \& DaEBeler, F. 1986. Neuere Gesichtspunkte bei der Handhabung des Bekämpfungsrichtwertes für den Rapsglanzkäfer: Recent aspects regarding the standard value for blossom rape beetle control. Nachr.bl. Pfl.schutz 40: 58-61.

W and without a ley. Results from trial series R4-1103. Växtodling 1989, No. 13.26 p.

WEBER, E. von \& BLEIHOLDER, H. 1990. Erläuterung zu den BBCH-Decimal-Codes fur die Entwicklungsstadien von Mais, Raps, Faba-Bohne, Sonnenblume und Erbse - mit Abbildungen. Gesunde Planzen 42: 308-321.

\section{Manuscript received February 1993}

\section{Sirpa Kurppa}

Antti Ollula

Agricultural Research Centre of Finland

Institute of Plant Protection

FIN-31600 Jokioinen, Finland

\title{
SELOSTUS
}

\section{Kevätrypsin tuhohyönteistorjunnan ja typpilannoituksen optimointi}

\author{
SirPa KuRPPA ja ANTTI Ollula
}

Maatalouden tutkimuskeskus

Maatalouden tutkimuskeskuksessa tutkittiin vuosina 1991 ja 1992 kevätrypsin kasvinsuojelun ja lannoituksen yhdysvaikutuksia. Tuholaistorjunnan tarvetta ei voitu ratkaisevasti vähentää lisälannoituksen avulla kasvustoissa, joissa taimettumisvaiheen kasvutiheys oli noin $300 \mathrm{kasvia} / \mathrm{m} 2$. Lisälannoituksen vaikutus tuli esiin parhaimmillaan noin $400 \mathrm{~kg} / \mathrm{ha}$ sadonlisänä eli huomattavasti vähäisempänä kuin tuhoeläintorjunnan vaikutus satoon, joka oli parhaimmillaan yli 1000 $\mathrm{kg} / \mathrm{ha}$. Rypsi pyrki korvaamaan rapsikuoriaisen vioituksia sivuhaarojen, litujen ja siementen lukumäärää lisäämällä. Vioitusten korvautuvuuden huipputaso saavutettiin jo kohtuullisella (90 - $110 \mathrm{~N} \mathrm{kg/ha)} \mathrm{lannoitustasolla,} \mathrm{ja} \mathrm{korvautuva}$ osuus jäi noin $30 \%$ runsaan kuoriaiskannan aiheuttamasta sadon menetyksestä. Sadon menetys korvautui kokonaan, kun kuoriaismäärä ylitti vain niukasti kynnysarvon, 1 kuoriainen/kasvi aikaisella nuppuasteella. Kirppojen vioitukset korvaantuivat varsin hyvin, mutta rypsin peittaus oli tarpeen kylvösiemenen taimivaiheen tuhojen estämiseksi ja taimettumisen varmistamiseksi kuivina ja erityisen lämpiminä kausina, jolloin kynnysarvo 30 reikää/kasvi ylittyi. Tällöin peittauksen laiminlyönti aiheutti torjuntaruiskutuksen tarpeen. Runsaan rapsikuoriaisesiintymän tehokas torjunta edellytti yleensä kahta torjuntaruiskutusta. Kasvunsääteiden ja juolavehnäntorjunta-aineiden liian intensiivinen käyttö johti satotason alenemiseen. Kohtuullinen lannoitustaso $(90-110 \mathrm{~kg}$ $\mathrm{N} / \mathrm{ha}$ ) oli riittävä parhaan katetuoton saavuttamiseksi jopa raskailla kivennäismailla. 